\title{
Ocular immune privilege and ocular melanoma: parallel universes or immunological plagiarism?
}

\section{Jerry Y. Niederkorn*}

Department of Ophthalmology, University of Texas Southwestern Medical Center, Dallas, TX, USA

\section{Edited by:}

Rachel R. Caspi, National Institutes of Health, USA

\section{Reviewed by:}

Joan Stein-Streilein, Schepens Eye

Research Institute, USA

Bruce Ksander, Harvard Medical

School, USA

\section{*Correspondence:}

Jerry Y. Niederkorn, Department of

Ophthalmology, University of Texas

Southwestern Medical Center, 5323

Harry Hines Blvd., Dallas, TX

75390-9057, USA.

e-mail: jerry.niederkorn@

utsouthwestern.edu
Evidence of immune privilege in the eye was recorded almost 140 years ago, yet interest in immune privilege languished for almost a century. However, the past 35 years have witnessed a plethora of research and a rekindled interest in the mechanisms responsible for immune privilege in the anterior chamber of the eye. This research has demonstrated that multiple anatomical, structural, physiological, and immunoregulatory processes contribute to immune privilege and remind us of the enormous complexity of this phenomenon. It is widely accepted that immune privilege is an adaptation for reducing the risk of immunemediated inflammation in organs such as the eye and brain whose tissues have a limited capacity to regenerate. Recent findings suggest that immune privilege also occurs in sites where stem cells reside and raise the possibility that immune privilege is also designed to prevent the unwitting elimination of stem cells by immune-mediated inflammation at these sites. Uveal melanoma arises within the eye and as such, benefits from ocular immune privilege. A significant body of research reveals an intriguing parallel between the mechanisms that contribute to immune privilege in the eye and those strategies used by uveal melanoma cells to evade immune elimination once they have disseminated from the eye and establish metastatic foci in the liver. Uveal melanoma metastases seem to have "plagiarized" the blueprints used for ocular immune privilege to create "ad hoc immune privileged sites" in the liver.

Keywords: anterior chamber, eye, immune privilege, stem cells, uveal melanoma

\section{INTRODUCTION}

The roots of immune privilege reach back two centuries to an observation made by the Dutch ophthalmologist van Dooremaal (1873). In an attempt to identify the etiology of cataracts van Dooremaal inserted a variety of foreign objects and tissues into the eyes of rabbits and dogs. Although he failed to discover the cause of cataracts, he observed a significant prolongation in the survival of mouse skin grafts placed into the anterior chamber (AC) of the dog eye (van Dooremaal, 1873). Another 75 years would pass before Medawar "rediscovered" the prolonged survival of foreign tissue grafts placed into the $\mathrm{AC}$ of rabbits and coined the term "immune privilege" to describe this phenomenon (Medawar, 1948). Medawar concluded that the apparent absence of lymphatic drainage from the AC resulted in a sequestration of antigens in the eye resulting in a condition that contemporary immunologists might call "immunological ignorance." The late 1970s ushered in a new era in immune privilege research that was led by Streilein and colleagues who made the remarkable observation that antigens introduced into the $\mathrm{AC}$ of the eye not only gained access to the peripheral lymphoid tissues, but in the process, induced a systemic down regulation of antigenspecific cell-mediated immunity (Kaplan et al., 1975; Kaplan and Streilein, 1977, 1978). This immunoregulatory phenomenon was termed AC-associated immune deviation (ACAID; Streilein and Niederkorn, 1981). The discovery of ACAID kindled a renewed interest in immune privilege research that has led to numerous insights over the past 35 years. This body of work has revealed that immune privilege is the product of multiple anatomical, physiological, and immunoregulatory processes that share a common feature - restriction of immune inflammation in an organ whose tissues have a severely limited capacity to regenerate.

In addition to the AC of the eye, there are other notable immune privileged sites in the body including the testis, hair follicle, placenta, and brain. The eye is part of the brain, both anatomically and embryologically, and like the brain, has a severely limited capacity to regenerate its tissues. Thus, immune privilege is believed to be an adaptation to protect the eye and the brain from injury inflicted by immune-mediated inflammation. By contrast, the testis, hair follicle, and placenta are sites where stem cells reside. Protecting stem cells from immune-mediated elimination has obvious survival benefits for the host and in the case of the placenta, for the survival of the species. It is noteworthy that many of the mechanisms that sustain immune privilege in the central nervous system (i.e., eye and brain) are also employed in sites where stem cells reside (e.g., testis, hair follicle, and placenta) and by stem cells themselves (Arck et al., 1997; Moffett-King, 2002; Aluvihare et al., 2004, 2005; Niederkorn, 2006; Robertson et al., 2007; Fujisaki et al., 2011; Kinori et al., 2011; Meinhardt and Hedger, 2011; Mital et al., 2011).

The immune system is functionally divided into two basic components: (a) innate immunity and (b) adaptive immunity. The innate immune response is characterized by its rapid activation 
and its conspicuous absence of antigen specificity and memory. Components of the innate immune apparatus include natural killer (NK) cells, macrophages, granulocytes, and the alternative pathway for complement activation. Elements of the innate immune response serve as "first responders" to infections and provide a nimble, albeit limited level of protection, which is replaced by the adaptive immune response. The adaptive immune system is characterized by its exquisite antigen specificity and memory. Although slower to develop, the adaptive immune response provides a comprehensive protection that persists longer than the innate immune response and possesses memory that allows for a rapid reactivation to future encounters with pathogens. Both innate and adaptive immune responses are capable of inflicting irreparable injury to ocular tissues and stem cells.

\section{IMMUNE PRIVILEGE AND THE INNATE IMMUNE RESPONSE}

Innate immune responses have the potential to inflict significant irreparable damage to the eye. Granulocytes and macrophages elaborate a variety of proteases and reactive oxygen species (ROS) that are known to damage innocent bystander cells. However, the aqueous humor $(\mathrm{AH})$ that fills the $\mathrm{AC}$ is endowed with a variety of anti-inflammatory and immunosuppressive cytokines, as well as free radical scavengers that buffer or neutralize proinflammatory cytokines and ROS (Taylor, 2007). Moreover, AH contains factors that induce apoptosis of neutrophils and macrophages (D'Orazio et al., 1999). The complement cascade can be activated through the alternative pathway through exposure to bacterial products and under such conditions it functions as a component of the innate immune system. Complement activation culminates in the generation of a membrane attack complex (MAC) that punches holes in the plasma membrane, which leads to osmotic lysis of both bacterial and mammalian cells. Activation of the complement cascade also generates soluble factors that recruit and activate neutrophils. However, injury inflicted by complement activation is minimized by complement regulatory proteins (CRPs) that are present in the $\mathrm{AH}$ and that also decorate the membranes of cells lining the AC (Lass et al., 1990; Bora et al., 1993; Goslings et al., 1996, 1998; Sohn et al., 2000a).

Natural killer cells are members of the innate immune system and are believed to protect against viral infections and neoplasms while the adaptive immune response is still being generated. Cytotoxic T lymphocytes (CTLs) are important elements of the adaptive immune response to viral infections and neoplasms. CTLs recognize viral antigens and tumor antigens that are displayed on major histocompatibility complex (MHC) class I molecules. MHC class I molecules act as the "docking station" that facilitates the binding and cytolytic activity of CTLs. However, to evade CTLmediated killing many tumors and viruses down-regulate MHC class I molecules and thereby render the cancer cells and virusinfected cells invisible to CTLs. To compensate for this evasive strategy, the immune system enlists the aid of NK cells, which are programmed to kill any cell failing to express MHC class I molecules. However, the corneal endothelial cells that line the AC of the eye and cells in the various layers of the retina express little or no MHC class I molecules and are therefore potentially vulnerable to NK cell-mediated cytolysis. Moreover, corneal endothelial cells and cells of the retina are amitotic and cannot regenerate. However, the AH contains two cytokines that inhibit NK cell-mediated cytolytic activity. Macrophage migration inhibitory factor (MIF) produces an immediate inhibition of NK cell-mediated cytolysis of corneal endothelial cells (Apte and Niederkorn, 1996). Transforming growth factor- $\beta$ (TGF- $\beta$ ) also inhibits NK cell-mediated cytolysis, but does not produce maximal inhibition for $22-24 \mathrm{~h}$ (Apte and Niederkorn, 1996). Thus, the AH is endowed with molecules that produce both immediate and delayed inhibition of NK cell activity. In addition to soluble inhibitory factors, the cells lining the AC express non-classical MHC class Ib molecules such as HLA$\mathrm{E}$ in humans and Qa-2 in mice, which can transmit "off" signals to NK cells (Niederkorn et al., 1999; Le Discorde et al., 2003). The importance of intraocular inhibition of NK cell activity was confirmed in studies in which NK-sensitive human uveal melanoma cells were transplanted either subcutaneously (SC) or into the AC of nude mice. Although nude mice lack a functional T cell repertoire, they display potent NK cell activity. Human uveal melanoma cells were briskly rejected by an NK cell-dependent process when they were transplanted SC in nude mice, but grew progressively in the eyes, even at doses that were 50-times lower than the doses that were rejected following SC transplantation (Apte et al., 1997).

Immune privilege of innate immune responses is also present in sites where stem cells reside such as the hair follicle, placenta, and testis. MIF is expressed in the hair follicle (Ito et al., 2008), Leydig cells of the testis (Meinhardt et al., 1996; Okuma et al., 2005), and in the placenta (Vigano et al., 2007). Moreover, there is a close association between reduced MIF in the hair follicle and the development of alopecia areata, an autoimmune disease of the skin (Ito et al., 2008). MIF produced by human decidual cells of the uterus inhibits the cytolytic activity of uterine NK cells and is believed to contribute to the immune privilege of the allogeneic fetus (Arcuri et al., 2006; Vigano et al., 2007). As mentioned earlier, non-classical class Ib MHC molecules are expressed in the eye and are believed to be important inhibitors of NK cell-mediated cytolysis. It is noteworthy that non-classical class Ib molecules are also expressed in the testis (Slukvin et al., 1999; Ryan et al., 2002) and in the placenta (Kovats et al., 1990; Ishitani and Geraghty, 1992; Rouas-Freiss et al., 1997, 1999). Thus, both soluble and cell membrane-bound molecules that inhibit innate immune responses are expressed in both the eye and in sites where stem cells reside (Table 1).

\section{IMMUNE PRIVILEGE AND THE ADAPTIVE IMMUNE RESPONSE}

The adaptive immune response is characterized by exquisite antigen specificity and memory. T cells and antibodies are the central players in adaptive immune responses and each has the capacity to produce injury to the eye. Many of the strategies employed to buffer injurious innate immune responses in the eye and in sites of stem cell residence are effective in blocking adaptive immune responses that have the potential to damage stem cells and ocular tissues that cannot regenerate.

\section{ANTI-INFLAMMATORY AND IMMUNOSUPPRESSIVE FACTORS}

The AH contains at least five factors that inhibit the expression of $\mathrm{T}$ cell-mediated inflammation: (a) TGF- $\beta$; (b) $\alpha$-melanocyte stimulating hormone $(\alpha-\mathrm{MSH})$; (c) vasoactive intestinal peptide (VIP); 
Table 1 | Factors that contribute to immune privilege in the eye and in sites of stem cell residence.

\begin{tabular}{|c|c|c|c|c|c|c|}
\hline Molecule & Mode of action & Eye & Placenta & $\mathbf{B M}$ & Testis & Hair follicle \\
\hline TGF- $\beta$ & Inhibit NK cell activity and promote generation of Tregs & Y & Y & Y & Y & Y \\
\hline MIF & Inhibit NK cell activity & Y & Y & $?$ & Y & Y \\
\hline MHC class Ib & Inhibit NK cell activity & Y & Y & $?$ & Y & Y \\
\hline IDO & Deplete tryptophan and induce T cell apoptosis & Y & Y & $?$ & Y & Y \\
\hline FasL & Induce apoptosis of T cells & Y & Y & $?$ & Y & $\mathrm{Y} / \mathrm{N}$ \\
\hline TRAIL & Inhibit T cell proliferation & Y & Y & $?$ & $?$ & $?$ \\
\hline CRPs & Inactivate complement & Y & Y & $?$ & $?$ & $?$ \\
\hline PD-L1 (B7-H1) & Inhibit T cell proliferation & Y & $?$ & $?$ & Y & $?$ \\
\hline Tregs & Inhibit T cell immunity & Y & Y & Y & Y & $?$ \\
\hline
\end{tabular}

$B M$, bone marrow; $Y$, yes; $Y / N$, indirect evidence; ?, not determined.

(d) calcitonin gene-related protein (CGRP); and (e) somatostatin (Granstein et al., 1990; Cousins et al., 1991; Taylor et al., 1994a,b; Taylor and Yee, 2003). Cells lining the AC also produce indoleamine dioxygenase (IDO), an enzyme that catabolizes tryptophan, which is a key amino acid that is necessary for T lymphocyte survival (Beutelspacher et al., 2006; Ryu and Kim, 2007). CRPs are present in the $\mathrm{AH}$ and are also expressed on the cell membranes of many cells lining the interior of the eye. CRPs are effective in maintaining immunological homeostasis within the eye. It is believed that a low level of complement activation is always present in the body, including the eye but under normal homeostatic conditions, CRPs act to restrain the untoward effects of complement activation. As evidence in support this, Sohn et al. (2000b) reported that administration of neutralizing antibody to CRPs in rats resulted in spontaneous ocular inflammation.

Immune privileged sites in which stem cells reside express many of the soluble factors that are found in the $\mathrm{AH}$ of the eye and are effective in suppressing adaptive immune responses (Table $\mathbf{1}$ ). TGF- $\beta$ is produced by Sertoli cells in the testis (Meinhardt and Hedger, 2011), in the hair follicle (Kinori et al., 2011), and by the placenta (Niederkorn, 2006). Moreover, murine embryonic stem cells (ESCs) themselves upregulate TGF- $\beta 2$ and create an " $a d$ hoc" immune privileged niche in the bone marrow (Robertson et al., 2007). The hair follicle, placenta, and Leydig cells of the testis elaborate $\alpha-\mathrm{MSH}$, which also suppresses T cell immunity in situ (Niederkorn, 2006; Kinori et al., 2011; Meinhardt and Hedger, 2011). Although it is not a secreted soluble factor, IDO acts to locally suppress $\mathrm{T}$ cell-mediated inflammation by depleting tryptophan and starving $\mathrm{T}$ cells. Interestingly, IDO is present in the anterior segment of the eye, in Sertoli cells of the testis, and in the placenta (Mellor et al., 2001; Beutelspacher et al., 2006; Fallarino et al., 2009).

Whether stem cells themselves contribute to the immune privilege in sites where they reside or whether they are beneficiaries of the local immunosuppressive properties of these regions remains unresolved. Numerous studies have reported that ESCs express very low levels of MHC class I molecules and virtually no class II and enjoy a significant degree of immune privilege (Drukker et al., 2002, 2006; Li et al., 2004a; Menard et al., 2005; Bonde and Zavazava, 2006). Moreover, adult stem cells (e.g., either mesenchymal or amniotic origin) themselves display immune privilege (Uccelli et al., 2008). By contrast, there is equally compelling evidence that ESCs are not inherently endowed with immune privilege and can undergo immune rejection (Nussbaum et al., 2007; Robertson et al., 2007; Chidgey and Boyd, 2008; Swijnenburg et al., 2008; Wu et al., 2008). Nonetheless, it is clear that many of the niches in which stem cells reside are classical immune privileged sites that provide a milieu that diminishes the likelihood of inflammation and immune-mediated injury.

\section{CELL MEMBRANE-BOUND MOLECULES}

Cells that line the interior of the eye express cell membrane-bound molecules that either induce apoptosis or inhibit proliferation of $\mathrm{T}$ cells entering the eye. FasL is expressed throughout the eye and purges activated $\mathrm{T}$ cells and neutrophils that enter the eye in response to viral infections or corneal transplants (Griffith et al., 1995; Stuart et al., 1997; Yamagami et al., 1997). PD-L1 is another member of the $\mathrm{B} 7$ family of membrane proteins that induce down regulation of $\mathrm{T}$ cell proliferation and cytokine production and promote apoptosis of inflammatory cells (Dong et al., 2002; Ding et al., 2005; Saunders et al., 2005; Okazaki and Honjo, 2007). PDL1 is expressed in both the mouse and human eye (Hori et al., 2006; Shen et al., 2007; Yang et al., 2009) and is necessary for the survival of corneal allografts (Hori et al., 2006; Shen et al., 2007). PD-L1 is upregulated in the eyes of patients with sympathetic ophthalmia and in ocular cells exposed to the proinflammatory cytokines such as TNF- $\alpha$ and IFN- $\gamma$, which suggests that PD-L1 serves as a buffer for dampening immune-mediated inflammation of the eye (Yang et al., 2009). Tumor necrosis factor-related apoptosis-inducing ligand (TRAIL) is a member of the TNF family and is expressed on cells lining the interior of the eye and is believed to contribute to ocular immune privilege in a manner similar to that invoked by PD-L1 (Lee et al., 2002; Wang et al., 2003).

Cell membrane-bound molecules are also expressed in stem cell niches. FasL is expressed on Sertoli cells of the testis (Bellgrau et al., 1995) and on the cells of the placenta (Niederkorn, 2006). FasL message is down-regulated in the hair follicles in patients with the autoimmune disease alopecia areata, which suggests that FasL is involved in maintaining immune privilege in the hair follicle (Kang et al., 2010). PD-L1 is found on Sertoli cells of the testis (Dal Secco et al., 2008) and on cells of the placenta (Petroff et al., 2003; Petroff, 2005; Holets et al., 2009). Thus, there is an interesting parallel in the mechanisms and molecules that 
sustain immune privilege in the eye and that shield stem cells from immune-mediated elimination.

\section{DYNAMIC IMMUNOREGULATORY PROCESSES THAT SUSTAIN IMMUNE PRIVILEGE}

In addition to soluble and cell membrane-bound molecules that dampen immune-mediated inflammation, immune privileged sites are designed to promote the generation of dynamic immunoregulatory processes that down-regulate adaptive immune responses. The seminal studies by Streilein and colleagues in the late 1970s introduced the paradigm of ACAID and the concept that immune privilege was also sustained by regulatory cells that deflected the adaptive immune response away from effector mechanisms that imposed extensive injury to collateral tissues. A plethora of studies have revealed the complex nature of ACAID and have demonstrated that at least four organ systems contribute to the generation of ACAID: (a) eye; (b) thymus; (c) spleen, and (d) sympathetic nervous system (Niederkorn, 2006, 2009; Niederkorn and Stein-Streilein, 2010). The induction of ACAID is initiated when antigens are introduced into the AC. Although it was originally believed that injecting antigens into the $\mathrm{AC}$ was tantamount to an intravenous (IV) injection, which is a well-known method for inducing immune tolerance (Asherson and Stone, 1965). However, the eye is not a passive participant in this process and the immune deviation induced by AC injection of antigens is fundamentally different from IV-induced immune deviation (Wilbanks and Streilein, 1990, 1991; Kosiewicz et al., 1998; Sonoda et al., 2001). Removal of the eye within 3 days of AC injection of antigen prevents the induction of ACAID. During this obligatory 3-day period, it is believed that antigen is captured by $\mathrm{F} 4 / 80^{+}$antigen presenting cells (APCs), which under the influence of cytokines in the AH are imprinted to preferentially produce IL-10 and downregulate the production of IL-12. The ocular APC emigrate from the eye to the thymus and spleen. Within the thymus the ocular APCs evoke the generation of $\mathrm{CD}^{-}, \mathrm{CD}^{-}, \mathrm{NK}^{-} .1^{+} \mathrm{T}$ cells (NKT cells), which subsequently emerge from the thymus and migrate to the spleen via the blood vascular route (Wang et al., 1997, 2001). Like the eye and spleen, the thymus is an active participant in the induction of ACAID. Removing the thymus within 3 days of AC injection of antigen prevents the induction of ACAID (Wang et al., 1997). The sympathetic nervous system is also an active player in the induction of AC AID, as chemical sympathectomy prevents the induction of ACAID (Li et al., 2004b). Although it is not clear how the sympathetic nervous system participates in the induction of ACAID, it appears that the generation of ocular $\mathrm{F} 4 / 80^{+}$APCs is not affected by the sympathetic nervous system (Li et al., 2004b). However, chemical sympathectomy prevents the generation of thymic NK1.1 $1^{+} \mathrm{T}$ cells and splenic $\mathrm{CD} 8^{+} \mathrm{T}$ regulatory cells ( $\mathrm{T}$ regs; Li et al., 2004b). A population of $\mathrm{F} 4 / 80^{+}$ocular APCs is also believed to migrate from the eye to the spleen where the APCs secrete MIP-2, which attracts $\mathrm{CD} 4^{+}$NKT cells, which in turn interact with the ocular APCs and secrete RANTES. RANTES recruits other cells into the marginal zone of the spleen. Within the marginal zone of the spleen, F $4 / 80^{+}$APCs, NKT cells, B cells, and $\mathrm{CD} 4^{+} \mathrm{T}$ cells, under the influence of the third component of complement, collaborate to generate antigen-specific $\mathrm{CD} 8^{+} \mathrm{T}$ (Figure 1).
Pigmented epithelial cells of the iris and ciliary body line a portion of the $\mathrm{AC}$ and exert important immunoregulatory effects. The ciliary body cells secrete $\mathrm{AH}$, which contains multiple immunosuppressive and anti-inflammatory molecules (Taylor et al., 1992, 1994a,b, 1997; Taylor and Yee, 2003; Taylor, 2007). In addition to secreting $\mathrm{AH}$, iris and ciliary body cells directly suppress $\mathrm{T}$ lymphocyte proliferation and block production of IFN- $\gamma$ by a contact-dependent process that is independent of the AH-borne soluble factors (Yoshida et al., 2000a). In vitro studies have shown that $\mathrm{T}$ lymphocytes co-cultured with iris and ciliary body cells acquire Treg activity that inhibits $\mathrm{T}$ lymphocyte proliferation and antigen-specific DTH (Yoshida et al., 2000b). The in situ generation of $\mathrm{T}$ regs requires direct contact between $\mathrm{T}$ lymphocytes and the iris and ciliary body cells. The locally generated $\mathrm{T}$ regs suppress inflammation by secreting active and latent forms of TGF- $\beta$. The only blood vessels in the anterior segment of the eye reside in the iris and ciliary body. Thus, inflammatory cells such as $\mathrm{T}$ lymphocytes that enter the AC of the eye extravasate via the iris and ciliary body blood vessels and as a result are in direct contact with the pigmented cells of the iris and ciliary body and thus, are subject to in situ induction of $\mathrm{T}$ reg activity. The in situ-generated $\mathrm{T}$ regs greet subsequent waves of inflammatory cells that enter the $\mathrm{AC}$ and impose their suppressive effects to further dampen inflammation in the AC.

The AC possesses a second pathway for the in situ generation of T regs. Soluble factors in the AH, namely $\alpha-\mathrm{MSH}$, can convert $\mathrm{T}$ lymphocytes into $\mathrm{CD} 4^{+} \mathrm{CD} 25^{+} \mathrm{T}$ regs that suppress DTH and extinguish immune-mediated inflammation such as experimental autoimmune uveitis (EAU; Nishida and Taylor, 1999; Taylor and Namba, 2001; Namba et al., 2002).

Local induction of $\mathrm{T}$ reg activity also occurs in sites where stem cells reside. The allogeneic fetus confronts the mother with alien histocompatibility antigens of paternal origin and thus, is at considerable risk for immune rejection. However, a wide array of anatomical, physiological, and immunoregulatory adaptations protect the fetus from immune rejection. The allogeneic fetus induces a form of immune deviation with striking parallels with ACAID. One might even argue that maternal immune privilege is initiated even before fertilization of the ovum. Seminal fluid contains one of the highest concentrations of TGF- $\beta$ of any bodily fluid (Robertson et al., 2002) and the TGF- $\beta$ concentration in the uterine luminal fluid increases over threefold immediately after insemination (Tremellen et al., 1998). Semen, like AH, has the capacity to promote the development of immune tolerance and $\mathrm{T}$ regs (Lengerova and Vojtiskova, 1963; Robertson et al., 1997; James et al., 2003). In both humans and mice, there is a steep increase in the number of $\mathrm{CD} 4^{+} \mathrm{CD} 25^{+} \mathrm{T}$ regs during pregnancy and depletion of $\mathrm{CD} 4{ }^{+} \mathrm{CD} 25^{+} \mathrm{T}$ regs induces abortion in mice (Aluvihare et al., 2004; Somerset et al., 2004). Induction of T regs also occurs in the testis. Soluble antigens injected into the testis induce a form of immune deviation that is reminiscent of ACAID (Li et al., 1997; Ditzian-Kadanoff, 1999; Verajankorva et al., 2002). A recent study demonstrated that allogeneic hematopoietic stem cell transplants reside in the bone marrow where immune reactivity exists, yet the stem cell transplants do not undergo immune rejection (Fujisaki et al., 2011). Allogeneic hematopoietic stem cells reside in the bone marrow in close proximity to $\mathrm{CD} 4{ }^{+} \mathrm{CD} 25^{+} \mathrm{T}$ regs. Interestingly, 


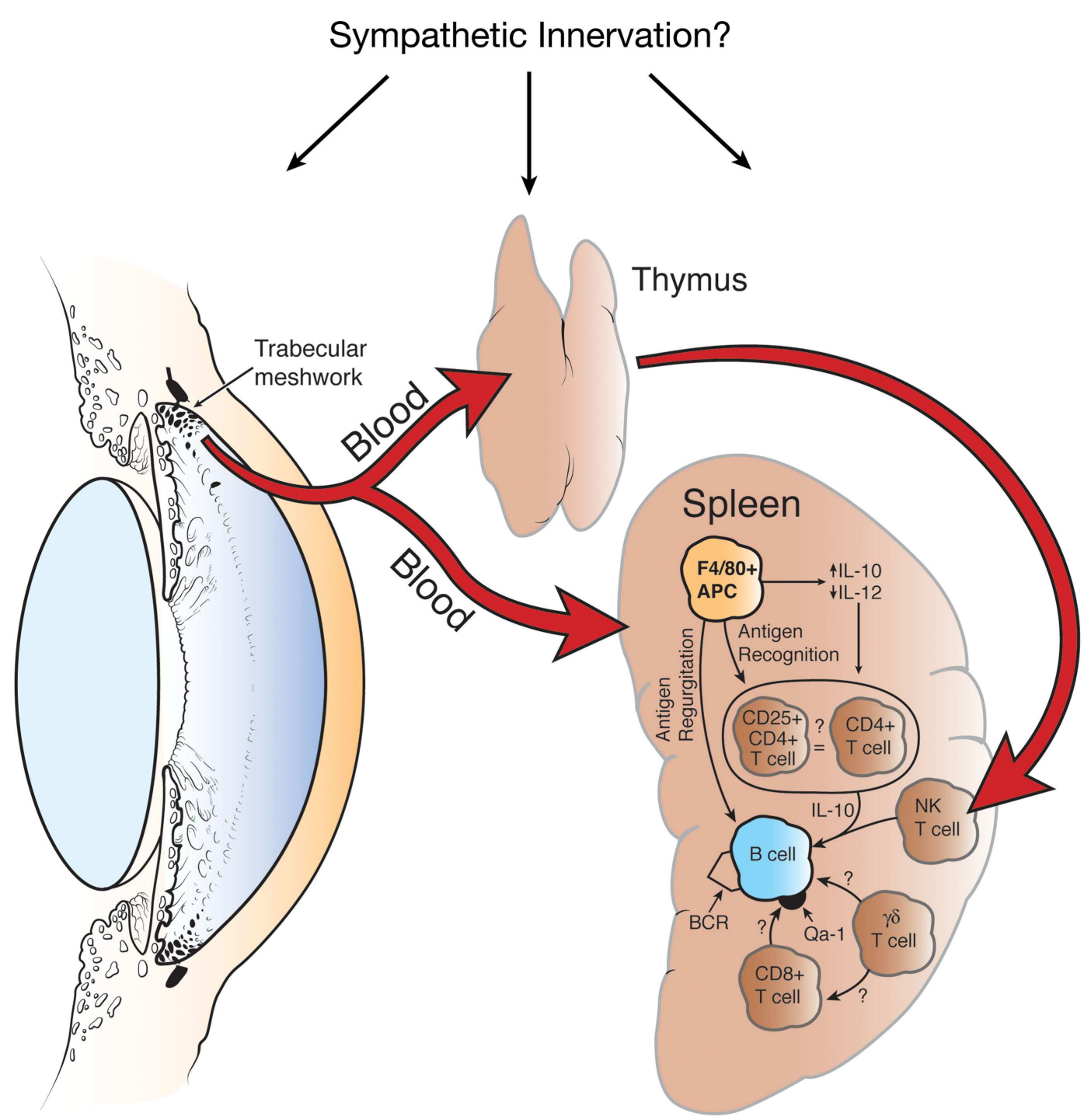

FIGURE 1 | Organ systems involved in the induction of ACAID. Removal of the eye, spleen, or thymus within $72 \mathrm{~h}$ of injecting antigen into the anterior chamber prevents the induction of ACAID. Chemical sympathectomy prior to injecting antigen into the anterior chamber also abrogates ACAID. BCR, B cell receptor. Reproduced from Niederkorn (2006), with permission from Nature Publishing Group. the hematopoietic stem cells are lost if the hosts are depleted of $\mathrm{CD}^{+}{ }^{+} \mathrm{CD} 25^{+}$T regs (Fujisaki et al., 2011). To date no studies have examined if the hair follicle environment promotes the induction of immune deviation or the generation of $\mathrm{T}$ regs (Kinori et al., 2011).

\section{OCULAR IMMUNE PRIVILEGE AND OCULAR MELANOMA:} PARALLEL UNIVERSES OR IMMUNOLOGICAL PLAGIARISM?

Uveal melanoma is the most common intraocular malignancy in adults and occurs with a frequency of seven cases per million per year in the Western world (Singh and Topham, 2003). There is ample evidence that uveal melanomas are recognized by elements of both the innate and adaptive immune responses. Although uveal melanomas reside within an immunologically privileged site and escape immune elimination in the eye, they metastasize to other body sites, which do not provide the same immunological sanctuary that occurs in the eye. However, growing evidence suggests that uveal melanomas have adopted many of the strategies that contribute to immune privilege in the eye and use them to escape immune rejection after the tumor cells have disseminated from the eye to distant body sites (Table 2).

\section{UVEAL MELANOMAS AND IMMUNE PRIVILEGE TO INNATE IMMUNE RESPONSES}

Studies in both humans and experimental animals indicate that the innate immune responses, namely NK cells, have an important influence on the growth and metastasis of uveal melanomas (Niederkorn, 2010). In vitro studies have shown that human uveal melanoma cells are susceptible to in vitro cytolysis by NK cells (Ma and Niederkorn, 1995; Ma et al., 1995; He et al., 2004). However, 
Table 2 | Mechanisms and molecules that maintain immune privilege in the eye and are "plagiarized" by uveal melanoma metastases to escape immune surveillance.

\begin{tabular}{|c|c|c|c|}
\hline $\begin{array}{l}\text { Mechanism/ } \\
\text { molecule }\end{array}$ & Mode of action & Eye & $\begin{array}{l}\text { Uveal } \\
\text { melanoma }\end{array}$ \\
\hline TGF- $\beta$ & Inhibit NK cells & Y & Y \\
\hline MIF & Inhibit NK cells & Y & Y \\
\hline IDO & Deplete T cells & Y & Y \\
\hline FasL & Deplete T cells & Y & Y \\
\hline TRAIL & $\begin{array}{l}\text { Inhibit T cell proliferation and } \\
\text { induce T cell apoptosis }\end{array}$ & Y & Y \\
\hline CRPs & Inactivate complement & Y & Y \\
\hline PD-L1 & $\begin{array}{l}\text { Inhibit T cell proliferation and } \\
\text { induce } \mathrm{T} \text { cell apoptosis }\end{array}$ & Y & Y \\
\hline $\begin{array}{l}\text { Low level of } \mathrm{MHC} \\
\text { class la }\end{array}$ & Escape detection by CTLs & Y & Y \\
\hline $\mathrm{MHC}$ class $\mathrm{lb}$ & Inhibit NK cells & Y & Y \\
\hline Tregs & Inhibit T cells & Y & $?$ \\
\hline
\end{tabular}

Y, yes; ?, not determined.

the susceptibility of uveal melanoma cells to NK cell-mediated lysis is inversely correlated with the expression of MHC class I molecules (Ma and Niederkorn, 1995; Ma et al., 1995) and is consistent with the "missing self" hypothesis, which posits that NK cells are programmed to kill any cell, malignant or non-malignant, that fails to express MHC class I molecules (Ljunggren and Karre, 1990). However, within the eye uveal melanomas are shielded from NK cell-mediated cytolysis by the buffering effects of the $\mathrm{AH}$, which contains two potent inhibitors of NK cell activity: TGF- $\beta$ and MIF. Both of these cytokines are present in the $\mathrm{AH}$ at concentrations that strongly inhibit NK cell-mediated cytolysis (Apte and Niederkorn, 1996; Apte et al., 1997, 1998). Experiments in nude mice have provided compelling evidence that $\mathrm{AH}$-borne factors prevent $\mathrm{NK}$ cell-mediated elimination of uveal melanomas in the eye. Nude mice lack a functional $\mathrm{T}$ lymphocyte repertoire, yet have a robust NK cell population. Uveal melanoma cells were briskly rejected following subcutaneous transplantation in nude mice, yet grew progressively if transplanted into the eye, even at doses 50 -fold lower than the subcutaneous doses (Apte et al., 1997). Elimination of NK cells by intraperitoneal injection of anti-asialo GM1 antiserum prevented nude mice from rejecting subcutaneously injected uveal melanoma cells and confirmed that the rejection of the subcutaneously injected uveal melanoma cells was indeed mediated by NK cells and also indicated that NK cell-mediated rejection of uveal melanoma cells can occur outside of the eye (Apte et al., 1997).

Uveal melanomas have a propensity to metastasize to the liver and $95 \%$ of the patients who die from uveal melanoma have liver metastases (Einhorn et al., 1974; Donoso et al., 1985). Lymphocytes can infiltrate primary uveal melanomas and in some cases, as many as $40 \%$ of the tumor-infiltrating lymphocytes (TIL) express NK cell markers (Ksander et al., 1991; Meecham et al., 1992; de Waard-Siebinga et al., 1996). Moreover, NK cells isolated from uveal melanoma-containing eyes display NK cell-mediated cytolytic activity (Ksander et al., 1991). However, as mentioned earlier, the AH of the eye contains MIF and TGF- $\beta$, both of which inhibit NK cell-mediated cytolytic activity in vitro and in situ. However, once in the liver, uveal melanoma cells find themselves in an environment that has the highest concentration of NK cells of any organ in the body (Godfrey et al., 2000; Crispe, 2009; Gao et al., 2009; Nemeth et al., 2009). To compensate for this harsh new reality, uveal melanomas have adopted the strategies employed by the eye to block NK cell-mediated cytolysis. In one study, liver metastases of uveal melanomas produced approximately twice as much MIF as primary uveal melanoma cells (Repp et al., 2000). Uveal melanomas also express TGF- $\beta 2$, the isoform of TGF- $\beta$ that suppresses NK cell activity (Esser et al., 2001). Verbik et al. (1997) examined the expression of MHC class I molecules on primary uveal melanomas and liver metastases from the same patient and discovered that liver metastases expressed a 10-fold higher expression of MHC class I molecules compared to the primary melanoma. The susceptibility of tumor cells to NK cell-mediated cytolysis is also affected by the tumor cell's expression of NK cell activating ligands. NKG2D is an activating receptor that is expressed on NK cells and when it interacts with its ligand, MIC$\mathrm{A} / \mathrm{B}$, which is expressed on NK-sensitive tumors, it transmits an activating signal that results in NK cell-mediated cytolysis of the tumor cells. An interesting recent study reported that MIC-A/B was expressed on $50 \%$ of primary uveal melanomas, but was undetectable on all 11 metastases specimens tested (Vetter et al., 2004). Thus, uveal melanomas appear to undergo a selection process once they leave the eye that favors the survival of cells that are resistant to NK cell-mediated cytolysis.

\section{UVEAL MELANOMAS AND IMMUNE PRIVILEGE TO ADAPTIVE IMMUNE RESPONSES}

Uveal melanomas have also high-jacked strategies used by the eye to create "ad hoc" immune privilege against adaptive immune responses in the liver.

\section{IDO AND THE STARVATION OF T CELLS}

$T$ lymphocytes are incapable of generating tryptophan and perish if this amino acid is absent. The enzyme IDO catalyzes the degradation of tryptophan and thereby terminates $\mathrm{T}$ lymphocyte immune responses (Munn et al., 1999; Frumento et al., 2002; Mellor et al., 2002; Terness et al., 2002). IDO is expressed in many ocular tissues and is believed to contribute to the immune privilege of corneal allografts (Malina and Martin, 1993; Beutelspacher et al., 2006; Ryu and Kim, 2007). IDO is expressed by some tumors and is believed to be a strategy for evading immune surveillance (Uyttenhove et al., 2003). Chen et al. (2007) reported that neither primary uveal melanomas nor liver metastases constitutively expressed IDO. However uveal melanoma cells exposed to IFN- $\gamma$, a cytokine produced by both T lymphocytes and NK cells, rapidly upregulated biologically active IDO. Thus, uveal melanoma cells are poised to generate IDO if they perceive the presence of either adaptive or innate immune elements and thereby evade immune elimination in the liver.

\section{COUNTER ATTACK BY PD-L1}

$\mathrm{PD}-\mathrm{L} 1$ is expressed throughout the eye and sustains immune privilege by down-regulating $\mathrm{T}$ lymphocyte proliferation and inducing 
apoptosis of inflammatory cells expressing its receptor, PD-1. PD$\mathrm{L} 1$ also contributes to the immune privilege of corneal allografts (Hori et al., 2006; Shen et al., 2007). In a recent study, approximately half of the primary uveal melanoma cell lines tested constitutively expressed PD-L1 and only $20 \%$ of the metastases cell lines were positive (Yang et al., 2009). However, exposure to the proinflammatory cytokine IFN $-\gamma$ resulted in the expression of PD-L1 on primary and metastases cell lines. Thus, uveal melanomas have the capacity to sense the presence of an inflammatory response in the form of IFN- $\gamma$ and respond by upregulating molecules such as IDO and PD-L1 that launch a counter attack that extinguishes immune-mediated inflammation directed against uveal melanomas. However, this escape mechanism can be circumvented. Uveal melanoma cells transfected with the $\mathrm{T}$ cell co-stimulatory molecule, CD80, do not upregulate PD-L1 when exposed to IFN- $\gamma$ and instead, activate T lymphocytes (Haile et al., 2011). This finding suggests that unraveling the mysteries of immune privilege may have important implications for designing therapeutic modalities for managing malignancies such as uveal melanoma that have adopted immune privilege as a strategy for escaping immune surveillance.

\section{BUFFERING EFFECTS CRPS}

Complement regulatory proteins are expressed in both soluble and cell membrane-bound forms throughout the eye and act as buffers to limit spontaneous inflammation and complement-mediated cytolysis of ocular cells. Uveal melanomas have high-jacked this strategy and express all three categories of CRPs (CD46, CD55, and CD59), which protect melanoma cells from complementmediated lysis in vitro and presumably in vivo (Goslings et al., 1996). There is evidence that at least one proinflammatory

\section{REFERENCES}

Aluvihare, V. R., Kallikourdis, M., and Betz, A. G. (2004). Regulatory T cells mediate maternal tolerance to the fetus. Nat. Immunol. 5, 266-271.

Aluvihare, V. R., Kallikourdis, M., and Betz, A. G. (2005). Tolerance, suppression and the fetal allograft. $J$. Mol. Med. 83, 88-96.

Apte, R. S., Mayhew, E., and Niederkorn, J. Y. (1997). Local inhibition of natural killer cell activity promotes the progressive growth of intraocular tumors. Invest. Ophthalmol. Vis. Sci. 38, 1277-1282.

Apte, R. S., and Niederkorn, J. Y. (1996). Isolation and characterization of a unique natural killer cell inhibitory factor present in the anterior chamber of the eye. J. Immunol. 156, 2667-2673.

Apte, R. S., Sinha, D., Mayhew, E., Wistow, G. J., and Niederkorn, J. Y. (1998). Cutting edge: role of macrophage migration inhibitory factor in inhibiting NK cell activity and preserving immune privilege. J. Immunol. 160, 5693-5696.

Arck, P. C., Ferrick, D. A., SteeleNorwood, D., Croitoru, K., and
Clark, D. A. (1997). Murine T cell determination of pregnancy outcome: I. Effects of strain, alphabeta $\mathrm{T}$ cell receptor, gammadelta $\mathrm{T}$ cell receptor, and gammadelta $\mathrm{T}$ cell subsets. Am. J. Reprod. Immunol. 37, 492-502.

Arcuri, F., Cintorino, M., Carducci, A., Papa, S., Riparbelli, M. G., Mangioni, S., Di Blasio, A. M., Tosi, P., and Vigano, P. (2006). Human decidual natural killer cells as a source and target of macrophage migration inhibitory factor. Reproduction 131, 175-182.

Asherson, G. L., and Stone, S. H. (1965). Selective and specific inhibition of 24 hour skin reactions in the guineapig. I. Immune deviation: description of the phenomenon and the effect of splenectomy. Immunology 9, 205-217.

Bellgrau, D., Gold, D., Selawry, H., Moore, J., Franzusoff, A., and Duke, R. C. (1995). A role for CD95 ligand in preventing graft rejection. Nature 377, 630-632.

Beutelspacher, S. C., Pillai, R., Watson, M. P., Tan, P. H., Tsang, J., McClure, M. O., George, A. J., and Larkin, D.

cytokine, TNF- $\alpha$, up regulates CRPs on uveal melanoma cells (Blom et al., 1997). Thus, like PD-L1 and IDO, CRPs have the capacity to be upregulated when inflammation and possibly adaptive immune effector elements are perceived.

\section{CONCLUSION AND PERSPECTIVES}

Our understanding of immune privilege has changed significantly over the past 50 years. What was originally perceived as an anatomical anomaly in which the putative absence of lymphatic channels in the eye and brain acted to sequester antigens and create a state of immunological ignorance has evolved into a more complex and dynamic phenomenon that is the sum total of processes and molecules that prevent the induction and expression of both innate and adaptive immunity. It is now widely accepted that immune privilege is an adaptation to protect organs such as the eye and brain, which have limited capacities to regenerate, from immunemediated injury. However, the same mechanisms and molecules that provide immune privilege to the eye and brain are also present in sites where stem cells reside and by stem cells themselves. Unwitting injury to stem cells by immune-mediated inflammation could have devastating consequences for the host's survival or in the case of the allogeneic fetus, for the survival of the species. Uveal melanomas have "plagiarized" the blueprints used by the eye to establish immune privilege and used them to escape immune surveillance once the tumors leave the eye and metastasize to the liver. Immune privilege in the eye is neither permanent nor absolute. A variety of maneuvers can ablate immune privilege in the eye. Perhaps the next phase of immune privilege research is to take the lessons we have learned in abrogating immune privilege and apply them to the treatment of uveal melanoma metastases.

F. (2006). Function of indoleamine 2,3-dioxygenase in corneal allograft rejection and prolongation of allograft survival by over-expression. Eur. J. Immunol. 36, 690-700.

Blom, D. J., Goslings, W. R., De WaardSiebinga, I., Luyten, G. P., Claas, F. H., Gorter, A., and Jager, M. J. (1997). Lack of effect of different cytokines on expression of membrane-bound regulators of complement activity on human uveal melanoma cells. J. Interferon Cytokine Res. 17, 695-700.

Bonde, S., and Zavazava, N. (2006). Immunogenicity and engraftment of mouse embryonic stem cells in allogeneic recipients. Stem Cells 24, 2192-2201.

Bora, N. S., Gobleman, C. L., Atkinson, J. P., Pepose, J. S., and Kaplan, H. J. (1993). Differential expression of the complement regulatory proteins in the human eye. Invest. Ophthalmol. Vis. Sci. 34, 3579-3584.

Chen, P. W., Mellon, J. K., Mayhew, E., Wang, S., He, Y. G., Hogan, N., and Niederkorn, J. Y. (2007). Uveal melanoma expression of indoleamine 2,3-deoxygenase establishment of an immune privileged environment by tryptophan depletion. Exp. Eye Res. 85, 617-625.

Chidgey, A. P., and Boyd, R. L. (2008). Immune privilege for stem cells: not as simple as it looked. Cell Stem Cell 3, 357-358.

Cousins, S. W., McCabe, M. M., Danielpour, D., and Streilein, J. W. (1991). Identification of transforming growth factor-beta as an immunosuppressive factor in aqueous humor. Invest. Ophthalmol. Vis. Sci. 32, 2201-2211.

Crispe, I. N. (2009). The liver as a lymphoid organ. Annu. Rev. Immunol. 27, 147-163.

Dal Secco, V., Riccioli, A., Padula, F. Ziparo, E., and Filippini, A. (2008). Mouse Sertoli cells display phenotypical and functional traits of antigen-presenting cells in response to interferon gamma. Biol. Reprod. 78, 234-242.

de Waard-Siebinga, I., Hilders, C. G., Hansen, B. E., van Delft, J. L., and Jager, M. J. (1996). HLA expression and tumor-infiltrating immune cells in uveal melanoma. Graefes Arch. Clin. Exp. Ophthalmol. 234, 34-42. 
Ding, H., Wu, X., and Gao, W. (2005). PD-L1 is expressed by human renal tubular epithelial cells and suppresses $\mathrm{T}$ cell cytokine synthesis. Clin. Immunol. 115, 184-191.

Ditzian-Kadanoff, R. (1999). Testicularassociated immune deviation and prevention of adjuvant-induced arthritis by three tolerization methods. Scand. J. Immunol. 50, 150-158.

Dong, H., Strome, S. E., Salomao, D. R., Tamura, H., Hirano, F., Flies, D. B., Roche, P. C., Lu, J., Zhu, G., Tamada, K., Lennon, V. A., Celis, E., and Chen, L. (2002). Tumor-associated B7-H1 promotes T-cell apoptosis: a potential mechanism of immune evasion. Nat. Med. 8, 793-800.

Donoso, L. A., Shields, J. A., Augsburger, J. J., Orth, D. H., and Johnson, P. (1985). Metastatic uveal melanoma: diffuse hepatic metastasis in a patient with concurrent normal serum liver enzyme levels and liver scan. Arch. Ophthalmol. 103, 758.

D’Orazio, T. J., DeMarco, B. M., Mayhew, E. S., and Niederkorn, J. Y. (1999). Effect of aqueous humor on apoptosis of inflammatory cell types. Invest. Ophthalmol. Vis. Sci. 40, 1418-1426.

Drukker, M., Katchman, H., Katz, G., Even-Tov Friedman, S., Shezen, E., Hornstein, E., Mandelboim, O., Reisner, Y., and Benvenisty, N. (2006). Human embryonic stem cells and their differentiated derivatives are less susceptible to immune rejection than adult cells. Stem Cells 24, 221-229.

Drukker, M., Katz, G., Urbach, A., Schuldiner, M., Markel, G., ItskovitzEldor, J., Reubinoff, B., Mandelboim, O., and Benvenisty, N. (2002). Characterization of the expression of MHC proteins in human embryonic stem cells. Proc. Natl. Acad. Sci. U.S.A. 99, 9864-9869.

Einhorn, L. H., Burgess, M. A., and Gottlieb, J. A. (1974). Metastatic patterns of choroidal melanoma. Cancer 34, 1001-1004.

Esser, P., Grisanti, S., and BartzSchmidt, K. (2001). TGF-beta in uveal melanoma. Microsc. Res. Tech. 52, 396-400.

Fallarino, F., Luca, G., Calvitti, M., Mancuso, F., Nastruzzi, C., Fioretti, M. C., Grohmann, U., Becchetti, E., Burgevin, A., Kratzer, R., van Endert, P., Boon, L., Puccetti, P., and Calafiore, R. (2009). Therapy of experimental type 1 diabetes by isolated Sertoli cell xenografts alone. J. Exp. Med. 206, 2511-2526.
Frumento, G., Rotondo, R., Tonetti, M., Damonte, G., Benatti, U., and Ferrara, G. B. (2002). Tryptophanderived catabolites are responsible for inhibition of $\mathrm{T}$ and natural killer cell proliferation induced by indoleamine 2,3-dioxygenase. J. Exp. Med. 196, 459-468.

Fujisaki, J., Wu, J., Carlson, A. L., Silberstein, L., Putheti, P., Larocca, R., Gao, W., Saito, T. I., Lo Celso, C., Tsuyuzaki, H., Sato, T., Cote, D., Sykes, M., Strom, T. B., Scadden, D. T., and Lin, C. P. (2011). In vivo imaging of Treg cells providing immune privilege to the haematopoietic stem-cell niche. Nature 474, 216-219.

Gao, B., Radaeva, S., and Park, O. (2009). Liver natural killer and natural killer $\mathrm{T}$ cells: immunobiology and emerging roles in liver diseases. J. Leukoc. Biol. 86, 513-528.

Godfrey, D. I., Hammond, K. J., Poulton, L. D., Smyth, M. J., and Baxter, A. G. (2000). NKT cells: facts, functions and fallacies. Immunol. Today 21, 573-583.

Goslings, W. R., Blom, D. J., de WaardSiebinga, I., van Beelen, E., Claas, F. H., Jager, M. J., and Gorter, A. (1996). Membrane-bound regulators of complement activation in uveal melanomas. CD46, CD55, and CD59 in uveal melanomas. Invest. Ophthalmol. Vis. Sci. 37, 1884-1891.

Goslings, W. R., Prodeus, A. P., Streilein, J. W., Carroll, M. C., Jager, M. J., and Taylor, A. W. (1998). A small molecular weight factor in aqueous humor acts on $\mathrm{Clq}$ to prevent antibody-dependent complement activation. Invest. Ophthalmol. Vis. Sci. 39, 989-995.

Granstein, R. D., Staszewski, R., Knisely, T. L., Zeira, E., Nazareno, R., Latina, M., and Albert, D. M. (1990). Aqueous humor contains transforming growth factor-beta and a small (less than 3500 daltons) inhibitor of thymocyte proliferation. J. Immunol. 144, 3021-3027.

Griffith, T. S., Brunner, T., Fletcher, S. M., Green, D. R., and Ferguson, T. A. (1995). Fas ligandinduced apoptosis as a mechanism of immune privilege. Science 270, 1189-1192.

Haile, S. T., Bosch, J. J., Agu, N. I., Zeender, A. M., Somasundaram, P., Srivastava, M. K., Britting, S., Wolf, J. B., Ksander, B. R., and Ostrand-Rosenberg, S. (2011). Tumor cell programmed death ligand 1-mediated $\mathrm{T}$ cell suppression is overcome by coexpression of CD80. J. Immunol. 186, 6822-6829.
He, Y. G., Mayhew, E., Mellon, J., and Niederkorn, J. Y. (2004). Expression and possible function of IL-2 and IL- 15 receptors on human uveal melanoma cells. Invest. Ophthalmol. Vis. Sci. 45, 4240-4246.

Holets, L. M., Carletti, M. Z., Kshirsagar, S. K., Christenson, L. K., and Petroff, M. G. (2009). Differentiation-induced posttranscriptional control of $\mathrm{B} 7-\mathrm{H} 1$ in human trophoblast cells. Placenta 30, 48-55.

Hori, J., Wang, M., Miyashita, M., Tanemoto, K., Takahashi, H., Takemori, T., Okumura, K., Yagita, H. and Azuma, M. (2006). B7-H1induced apoptosis as a mechanism of immune privilege of corneal allografts. J. Immunol. 177, 5928-5935.

Ishitani, A., and Geraghty, D. E. (1992). Alternative splicing of HLA-G transcripts yields proteins with primary structures resembling both class I and class II antigens. Proc. Natl. Acad. Sci. U.S.A. 89, 3947-3951.

Ito, T., Ito, N., Saatoff, M., Hashizume, H., Fukamizu, H., Nickoloff, B. J., Takigawa, M., and Paus, R. (2008). Maintenance of hair follicle immune privilege is linked to prevention of NK cell attack. J. Invest. Dermatol. 128, 1196-1206.

James, E., Chai, J. G., Dewchand, H., Macchiarulo, E., Dazzi, F., and Simpson, E. (2003). Multiparity induces priming to male-specific minor histocompatibility antigen, $\mathrm{HY}$, in mice and humans. Blood 102, 388-393.

Kang, H., Wu, W. Y., Lo, B. K., Yu, M., Leung, G., Shapiro, J., and McElwee, K. J. (2010). Hair follicles from alopecia areata patients exhibit alterations in immune privilege-associated gene expression in advance of hair loss. J. Invest. Dermatol. 130, 2677-2680.

Kaplan, H. J., Stevens, T. R., and Streilein, J. W. (1975). Transplantation immunology of the anterior chamber of the eye. I. An intra-ocular graft-vs-host reaction (immunogenic anterior uveitis). $J$. Immunol. 115, 800-804.

Kaplan, H. J., and Streilein, J. W. (1977). Immune response to immunization via the anterior chamber of the eye. I.F. lymphocyte-induced immune deviation. J. Immunol. 118, 809-814.

Kaplan, H. J., and Streilein, J. W. (1978). Immune response to immunization via the anterior chamber of the eye. II. An analysis of F1 lymphocyte-induced immune deviation. J. Immunol. 120, 689-693.

Kinori, M., Kloepper, J. E., and Paus, R. (2011). Can the hair follicle become a model for studying selected aspects of human ocular immune privilege? Invest. Ophthalmol. Vis. Sci. 52, 4447-4458.

Kosiewicz, M. M., Alard, P., and Streilein, J. W. (1998). Alterations in cytokine production following intraocular injection of soluble protein antigen: impairment in IFNgamma and induction of TGF- beta and IL-4 production. J. Immunol. 161, 5382-5390.

Kovats, S., Main, E. K., Librach, C., Stubblebine, M., Fisher, S. J., and DeMars, R. (1990). A class I antigen, HLA$\mathrm{G}$, expressed in human trophoblasts. Science 248, 220-223.

Ksander, B. R., Rubsamen, P. E., Olsen, K. R., Cousins, S. W., and Streilein, J. W. (1991). Studies of tumor-infiltrating lymphocytes from a human choroidal melanoma. Invest. Ophthalmol. Vis. Sci. 32, 3198-3208.

Lass, J. H., Walter, E. I., Burris, T. E., Grossniklaus, H. E., Roat, M. I., Skelnik, D. L., Needham, L., Singer, M. and Medof, M. E. (1990). Expression of two molecular forms of the complement decay-accelerating factor in the eye and lacrimal gland. Invest. Ophthalmol. Vis. Sci. 31, 1136-1148.

Le Discorde, M., Moreau, P., Sabatier P., Legeais, J. M., and Carosella, E. D. (2003). Expression of HLA$\mathrm{G}$ in human cornea, an immuneprivileged tissue. Hum. Immunol. 64, 1039-1044.

Lee, H. O., Herndon, J. M., Barreiro, R., Griffith, T. S., and Ferguson, T. A. (2002). TRAIL: a mechanism of tumor surveillance in an immune privileged site. J. Immunol. 169 , 4739-4744.

Lengerova, A., and Vojtiskova, M. (1963). Prolonged survival of syngeneic male skin grafts in parous C57B1 mice. Folia Biol. (Praha) 9, 72-74.

Li, H., Ren, J., Dhabuwala, C. B., and Shichi, H. (1997). Immunotolerance induced by intratesticular antigen priming: expression of TGF-beta, Fas and Fas ligand. Ocul. Immunol. Inflamm. 5, 75-84.

Li, L., Baroja, M. L., Majumdar, A., Chadwick, K., Rouleau, A., Gallacher, L., Ferber, I., Lebkowski, J., Martin, T., Madrenas, J., and Bhatia, M. (2004a). Human embryonic stem cells possess immuneprivileged properties. Stem Cells 22, $448-456$.

Li, X., Taylor, S., Zegarelli, B., Shen, S., O'Rourke, J., and Cone, R. E. (2004b). The induction of splenic suppressor $\mathrm{T}$ cells through an immune-privileged site requires an 
intact sympathetic nervous system. J. Neuroimmunol. 153, 40-49.

Ljunggren, H. G., and Karre, K. (1990). In search of the 'missing self': MHC molecules and NK cell recognition. Immunol. Today 11, 237-244.

Ma, D., Luyten, G. P., Luider, T. M., and Niederkorn, J. Y. (1995). Relationship between natural killer cell susceptibility and metastasis of human uveal melanoma cells in a murine model. Invest. Ophthalmol. Vis. Sci. $36,435-441$

Ma, D., and Niederkorn, J. Y. (1995). Transforming growth factor-beta down-regulates major histocompatibility complex class I antigen expression and increases the susceptibility of uveal melanoma cells to natural killer cell-mediated cytolysis. Immunology 86, 263-269.

Malina, H. Z., and Martin, X. D. (1993). Indoleamine 2,3-dioxygenase activity in the aqueous humor, iris/ciliary body, and retina of the bovine eye. Graefes Arch. Clin. Exp. Ophthalmol. 231, 482-486.

Medawar, P. B. (1948). Immunity to homologous grafted skin. III. The fate of skin homografts transplanted to the brain, to subcutaneous tissue, and to the anterior chamber of the eye. Br. J. Exp. Pathol. 29, 58-69.

Meecham, W. J., Char, D. H., and KaletaMichaels, S. (1992). Infiltrating lymphocytes and antigen expression in uveal melanoma. Ophthalmic Res. $24,20-26$.

Meinhardt, A., Bacher, M., McFarlane, J. R., Metz, C. N., Seitz, J., Hedger, M. P., de Kretser, D. M., and Bucala, R. (1996). Macrophage migration inhibitory factor production by Leydig cells: evidence for a role in the regulation of testicular function. Endocrinology 137, 5090-5095.

Meinhardt, A., and Hedger, M. P. (2011). Immunological, paracrine and endocrine aspects of testicular immune privilege. Mol. Cell. Endocrinol. 335, 60-68.

Mellor, A. L., Keskin, D. B., Johnson, T., Chandler, P., and Munn, D. H. (2002). Cells expressing indoleamine 2,3-dioxygenase inhibit $\mathrm{T}$ cell responses. J. Immunol. 168, 3771-3776.

Mellor, A. L., Sivakumar, J., Chandler, P., Smith, K., Molina, H., Mao, D., and Munn, D. H. (2001). Prevention of $\mathrm{T}$ cell-driven complement activation and inflammation by tryptophan catabolism during pregnancy. Nat. Immunol. 2, 64-68.

Menard, C., Hagege, A. A., Agbulut, O., Barro, M., Morichetti, M. C., Brasselet, C., Bel, A., Messas, E., Bissery, A., Bruneval, P., Desnos, M., Puceat, M., and Menasche, P. (2005). Transplantation of cardiac-committed mouse embryonic stem cells to infarcted sheep myocardium: a preclinical study. Lancet 366, 1005-1012.

Mital, P., Hinton, B. T., and Dufour, J. M. (2011). The blood-testis and blood-epididymis barriers are more than just their tight junctions. Biol. Reprod. 84, 851-858.

Moffett-King, A. (2002). Natural killer cells and pregnancy. Nat. Rev. Immunol. 2, 656-663.

Munn, D. H., Shafizadeh, E., Attwood, J. T., Bondarev, I., Pashine, A., and Mellor, A. L. (1999). Inhibition of T cell proliferation by macrophage tryptophan catabolism. J. Exp. Med. 189, 1363-1372.

Namba, K., Kitaichi, N., Nishida, T., and Taylor, A. W. (2002). Induction of regulatory $\mathrm{T}$ cells by the immunomodulating cytokines alpha-melanocyte-stimulating hormone and transforming growth factor-beta2. J. Leukoc. Biol. 72, 946-952.

Nemeth, E., Baird, A. W., and O'Farrelly, C. (2009). Microanatomy of the liver immune system. Semin. Immunopathol. 31, 333-343.

Niederkorn,J.Y. (2006). See no evil, hear no evil, do no evil: the lessons of immune privilege. Nat. Immunol. 7 , 354-359.

Niederkorn, J. Y. (2009). Immune escape mechanisms of intraocular tumors. Prog. Retin. Eye Res. 28, 329-347.

Niederkorn, J. Y. (2010). "NK cells in the eye," in Natural Killer Cells, eds M. T. Lotze and A. W. Thomson (Amsterdam: Academic Press), 385-401.

Niederkorn, J. Y., Chiang, E. Y., Ungchusri, T., and Stroynowski, I. (1999). Expression of a nonclassical MHC class Ib molecule in the eye. Transplantation 68, 1790-1799.

Niederkorn, J. Y., and Stein-Streilein, J. (2010). History and physiology of immune privilege. Ocul. Immunol. Inflamm. 18, 19-23.

Nishida, T., and Taylor, A. W. (1999). Specific aqueous humor factors induce activation of regulatory $\mathrm{T}$ cells. Invest. Ophthalmol. Vis. Sci. 40, 2268-2274.

Nussbaum, J., Minami, E., Laflamme, M. A., Virag, J. A., Ware, C. B., Masino, A., Muskheli, V., Pabon, L., Reinecke, H., and Murry, C. E. (2007). Transplantation of undifferentiated murine embryonic stem cells in the heart: teratoma formation and immune response. FASEB J. 21, 1345-1357.

Okazaki, T., and Honjo, T. (2007). PD1 and PD-1 ligands: from discovery to clinical application. Int. Immunol. 19, 813-824.

Okuma, Y., Saito, K., O’Connor, A. E., Phillips, D. J., de Kretser, D. M., and Hedger, M. P. (2005). Reciprocal regulation of activin A and inhibin B by interleukin-1 (IL-1) and folliclestimulating hormone (FSH) in rat Sertoli cells in vitro. J. Endocrinol. 185, 99-110.

Petroff, M. G. (2005). Immune interactions at the maternal-fetal interface. J. Reprod. Immunol. 68, 1-13.

Petroff, M. G., Chen, L., Phillips, T. A., Azzola, D., Sedlmayr, P., and Hunt, J. S. (2003). B7 family molecules are favorably positioned at the human maternal-fetal interface. Biol. Reprod. 68, 1496-1504.

Repp, A. C., Mayhew, E. S., Apte, S., and Niederkorn, J. Y. (2000). Human uveal melanoma cells produce macrophage migration-inhibitory factor to prevent lysis by NK cells. $J$. Immunol. 165, 710-715.

Robertson, N. J., Brook, F. A., Gardner, R. L., Cobbold, S. P., Waldmann, H., and Fairchild, P. J. (2007) Embryonic stem cell-derived tissues are immunogenic but their inherent immune privilege promotes the induction of tolerance. Proc. Natl. Acad. Sci. U.S.A. 104, 20920-20925.

Robertson, S. A., Ingman, W. V., O'Leary, S., Sharkey, D. J., and Tremellen, K. P. (2002). Transforming growth factor beta - a mediator of immune deviation in seminal plasma. J. Reprod. Immunol. 57 , 109-128.

Robertson, S. A., Mau, V. J., Hudson, S. N., and Tremellen, K. P. (1997) Cytokine-leukocyte networks and the establishment of pregnancy. Am J. Reprod. Immunol. 37, 438-442.

Rouas-Freiss, N., Goncalves, R. M., Menier, C., Dausset, J., and Carosella, E. D. (1997). Direct evidence to support the role of HLA-G in protecting the fetus from maternal uterine natural killer cytolysis. Proc. Natl. Acad. Sci. U.S.A. 94, 11520-11525.

Rouas-Freiss, N., Khalil-Daher, I., Marchal-Bras Goncalves, R., Menier, C., Dausset, J., and Carosella, E. D. (1999). Role of HLA-G in maternalfetal immune tolerance. Transplant. Proc. 31, 724-725.

Ryan, A. F., Grendell, R. L., Geraghty, D. E., and Golos, T. G. (2002). A soluble isoform of the rhesus monkey nonclassical MHC class I molecule Mamu-AG is expressed in the placenta and the testis. J. Immunol. 169, 673-683.

Ryu, Y. H., and Kim, J. C. (2007). Expression of indoleamine 2,3-dioxygenase in human corneal cells as a local immunosuppressive factor. Invest. Ophthalmol. Vis. Sci. 48, 4148-4152.

Saunders, P. A., Hendrycks, V. R., Lidinsky, W. A., and Woods, M. L. (2005). PD-L2:PD-1 involvement in T cell proliferation, cytokine production, and integrin-mediated adhesion. Eur. J. Immunol. 35, 3561-3569.

Shen, L., Jin, Y., Freeman, G. J., Sharpe, A. H., and Dana, M. R. (2007). The function of donor versus recipient programmed death-ligand 1 in corneal allograft survival. $J$. Immunol. 179, 3672-3679.

Singh, A. D., and Topham, A. (2003). Incidence of uveal melanoma in the United States: 1973-1997. Ophthalmology 110, 956-961.

Slukvin, I. I., Watkins, D. I., and Golos, T. G. (1999). Tissue distribution of the mRNA for a rhesus monkey major histocompatibility class Ib molecule, Mamu-AG. Tissue Antigens 53, 282-291.

Sohn, J. H., Kaplan, H. J., Suk, H. J., Bora, P. S., and Bora, N. S. (2000a). Complement regulatory activity of normal human intraocular fluid is mediated by MCP, DAF, and CD59. Invest. Ophthalmol. Vis. Sci. 41, 4195-4202.

Sohn, J. H., Kaplan, H. J., Suk, H. J., Bora, P. S., and Bora, N. S. (2000b). Chronic low level complement activation within the eye is controlled by intraocular complement regulatory proteins. Invest. Ophthalmol. Vis. Sci. 41, 3492-3502.

Somerset, D. A., Zheng, Y., Kilby, M. D., Sansom, D. M., and Drayson, M. T. (2004). Normal human pregnancy is associated with an elevation in the immune suppressive CD25+ CD4+ regulatory T-cell subset. Immunology $112,38-43$.

Sonoda, K. H., Faunce, D. E., Taniguchi, M., Exley, M., Balk, S., and SteinStreilein, J. (2001). NK T cell-derived IL-10 is essential for the differentiation of antigen- specific $\mathrm{T}$ regulatory cells in systemic tolerance. $J$. Immunol. 166, 42-50.

Streilein, J. W., and Niederkorn, J. Y. (1981). Induction of anterior chamber-associated immune deviation requires an intact, functional spleen. J. Exp. Med. 153, 1058-1067.

Stuart, P. M., Griffith, T. S., Usui, N., Pepose, J., Yu, X., and Ferguson, T. A. (1997). CD95 ligand (FasL)-induced apoptosis is necessary for corneal allograft survival. J. Clin. Invest. 99, 396-402.

Swijnenburg, R. J., Schrepfer, S., Govaert, J. A., Cao, F., Ransohoff, K., Sheikh, A. Y., Haddad, M., Connolly, A. J., Davis, M. M., Robbins, R. C., 
and Wu, J. C. (2008). Immunosuppressive therapy mitigates immunological rejection of human embryonic stem cell xenografts. Proc. Natl. Acad. Sci. U.S.A. 105, 12991-12996.

Taylor, A., and Namba, K. (2001). In vitro induction of CD25 + CD4+ regulatory $\mathrm{T}$ cells by the neuropeptide alpha-melanocyte stimulating hormone (alpha-MSH). Immunol. Cell Biol. 79, 358-367.

Taylor, A. W. (2007). Ocular immunosuppressive microenvironment. Chem. Immunol. 92, 71-85.

Taylor, A. W., Alard, P., Yee, D. G., and Streilein, J. W. (1997). Aqueous humor induces transforming growth factor-beta (TGF-beta)- producing regulatory T-cells. Curr. Eye Res. 16, 900-908.

Taylor, A. W., Streilein, J. W., and Cousins, S. W. (1992). Identification of alpha-melanocyte stimulating hormone as a potential immunosuppressive factor in aqueous humor. Curr. Eye Res. 11, 1199-1206.

Taylor, A. W., Streilein, J. W., and Cousins, S. W. (1994a). Alphamelanocyte-stimulating hormone suppresses antigen-stimulated $\mathrm{T}$ cell production of gamma-interferon. Neuroimmunomodulation 1 , 188-194.

Taylor, A. W., Streilein, J. W., and Cousins, S. W. (1994b). Immunoreactive vasoactive intestinal peptide contributes to the immunosuppressive activity of normal aqueous humor. J. Immunol. 153, 1080-1086.

Taylor, A. W., and Yee, D. G. (2003). Somatostatin is an immunosuppressive factor in aqueous humor. Invest. Ophthalmol. Vis. Sci. 44, 2644-2649.

Terness, P., Bauer, T. M., Rose, L., Dufter, C., Watzlik, A., Simon, H., and Opelz, G. (2002). Inhibition of allogeneic $\mathrm{T}$ cell proliferation by indoleamine 2,3-dioxygenaseexpressing dendritic cells: mediation of suppression by tryptophan metabolites. J. Exp. Med. 196, 447-457.
Tremellen, K. P., Seamark, R. F., and Robertson, S. A. (1998). Seminal transforming growth factor betal stimulates granulocyte-macrophage colony-stimulating factor production and inflammatory cell recruitment in the murine uterus. Biol. Reprod. 58, 1217-1225.

Uccelli, A., Moretta, L., and Pistoia, V. (2008). Mesenchymal stem cells in health and disease. Nat. Rev. Immunol. 8, 726-736.

Uyttenhove, C., Pilotte, L., Theate, I., Stroobant, V., Colau, D., Parmentier, N., Boon, T., and Van den Eynde, B. J. (2003). Evidence for a tumoral immune resistance mechanism based on tryptophan degradation by indoleamine 2,3-dioxygenase. Nat. Med. 9, 1269-1274.

van Dooremaal, J. C. (1873). Die Entwicklung der in fremden Grund versetzten lebenden Geweba. Albrecht Von Graefes Arch. Ophthalmol. 19, 358-373.

Verajankorva, E., Setala, N., Teros, T., Salmi, A. A., and Pollanen, P. (2002). Testicular-associated immune deviation: flushing of the testicular lymph sinusoids induces immunosuppression and inhibits formation of EAE in SJL mice. Scand. J. Immunol. 55, 478-483.

Verbik, D. J., Murray, T. G., Tran, J. M., and Ksander, B. R. (1997) Melanomas that develop within the eye inhibit lymphocyte proliferation. Int. J. Cancer 73, 470-478.

Vetter, C. S., Lieb, W., Brocker, E. B., and Becker, J. C. (2004). Loss of nonclassical MHC molecules MIC$\mathrm{A} / \mathrm{B}$ expression during progression of uveal melanoma. Br. J. Cancer 91, 1495-1499.

Vigano, P., Cintorino, M., Schatz, F., Lockwood, C. J., and Arcuri, F (2007). The role of macrophage migration inhibitory factor in maintaining the immune privilege at the fetal-maternal interface. Semin. Immunopathol. 29, 135-150.

Wang, S., Boonman, Z. F., Li, H. C., He, Y., Jager, M. J., Toes, R. E., and
Niederkorn, J. Y. (2003). Role of TRAIL and IFN-gamma in CD4+ $\mathrm{T}$ cell-dependent tumor rejection in the anterior chamber of the eye. $J$. Immunol. 171, 2789-2796.

Wang, Y., Goldschneider, I., Foss, D., Wu, D. Y., O'Rourke, J., and Cone, R. E. (1997). Direct thymic involvement in anterior chamberassociated immune deviation: evidence for a nondeletional mechanism of centrally induced tolerance to extrathymic antigens in adult mice. J. Immunol. 158, 2150-2155.

Wang, Y., Goldschneider, I., O'Rourke, J., and Cone, R. E. (2001). Blood mononuclear cells induce regulatory NK $\mathrm{T}$ thymocytes in anterior chamber-associated immune deviation. J. Leukoc. Biol. 69 , 741-746.

Wilbanks, G. A., and Streilein, J. W. (1990). Characterization of suppressor cells in anterior chamber-associated immune deviation (ACAID) induced by soluble antigen. Evidence of two functionally and phenotypically distinct T-suppressor cell populations. Immunology 71, 383-389.

Wilbanks, G. A., and Streilein, J. W. (1991). Studies on the induction of anterior chamber-associated immune deviation (ACAID). 1. Evidence that an antigen-specific, ACAID- inducing, cell-associated signal exists in the peripheral blood. J. Immunol. 146, 2610-2617.

Wu, D. C., Boyd, A. S., and Wood, K. J. (2008). Embryonic stem cells and their differentiated derivatives have a fragile immune privilege but still represent novel targets of immune attack. Stem Cells 26, 1939-1950.

Yamagami, S., Kawashima, H., Tsuru, T. Yamagami, H., Kayagaki, N., Yagita, H., Okumura, K., and Gregerson, D. S. (1997). Role of Fas-Fas ligand interactions in the immunorejection of allogeneic mouse corneal transplants. Transplantation 64 1107-1111.
Yang, W., Li, H., Chen, P. W., Alizadeh, H., He, Y., Hogan, R. N., and Niederkorn, J. Y. (2009). PD-L1 expression on human ocular cells and its possible role in regulating immune-mediated ocular inflammation. Invest. Ophthalmol. Vis. Sci. 50, 273-280.

Yoshida, M., Kezuka, T., and Streilein, J. W. (2000a). Participation of pigment epithelium of iris and ciliary body in ocular immune privilege. 2. Generation of TGFbeta-producing regulatory $\mathrm{T}$ cells. Invest. Ophthalmol. Vis. Sci. 41, 3862-3870.

Yoshida, M., Takeuchi, M., and Streilein, J. W. (2000b). Participation of pigment epithelium of iris and ciliary body in ocular immune privilege. 1. Inhibition of T-cell activation in vitro by direct cell-to-cell contact. Invest. Ophthalmol. Vis. Sci. 41, 811-821.

Conflict of Interest Statement: The author declares that the research was conducted in the absence of any commercial or financial relationships that could be construed as a potential conflict of interest.

Received: 20 March 2012; paper pending published: 16 April 2012; accepted: 21 May 2012; published online: 13 June 2012.

Citation: Niederkorn JY (2012) Ocular immune privilege and ocular melanoma: parallel universes or immunological plagiarism? Front. Immun. 3:148. doi: 10.3389/fimmu.2012.00148

This article was submitted to Frontiers in Immunological Tolerance, a specialty of Frontiers in Immunology.

Copyright (C) 2012 Niederkorn. This is an open-access article distributed under the terms of the Creative Commons Attribution Non Commercial License, which permits non-commercial use, distribution, and reproduction in other forums, provided the original authors and source are credited. 